\title{
Pancreatic serous cystadenoma - A case report
}

\author{
Grandhi B ${ }^{1}$, Shanthi $\mathrm{V}^{2}$, Rao NM${ }^{3}$, Reddy $\mathrm{VC}^{4}$, Mohan $\mathrm{KM}^{5}$, \\ ${ }^{1}$ Dr. Bhavana Grandhi, MD, Assistant Professor, ${ }^{2}$ Dr.Vissa Shanthi, MD, Associate Professor, ${ }^{3}$ Dr. Nandam Mohan Rao, \\ MD, Associate Professor, ${ }^{4}$ Dr.Vengala Chidananda Reddy, MD, DCP. Assistant Professor, Dept. of Pathology, ${ }^{5}$ Dr. Kuppili \\ Murali Mohan, Professor \& HOD. All are affiliated with NTR University of Health Sciences \& Department of Pathology, \\ Narayana Medical College, Nellore, Andhra Pradesh, India
}

Address for correspondence: Dr Bhavana Grandhi, Email: drbhavana.grandhi@gmail.com

\begin{abstract}
Microcystic serous cystadenoma is a benign tumor of pancreas, also termed as Clear cell or Glycogen rich adenoma. It occurs at any site in pancreas and composed of small cystic spaces lined by small cuboidal cells with clear cytoplasm, glycogen. There is an association with von Hippel Lindau syndrome in few cases. Clinical symptoms are variable. Excision is almost curative. We report a case of 70 year old male who presented to the OPD with vague complaints of local discomfort. Ultrasound showed a mass in the pancreas. Pancreatectomy was done and diagnosed as microcystic serous cystadenoma of pancreas on histopathology.
\end{abstract}

Keywords: Microcystic serous cystadenoma, Pancreatic tumours, Pancreactomy

\section{Introduction}

Serous cystic neoplasms constitute $10 \%$ of surgically resected cystic pancreatic neoplasms. It is a benign tumor with female predominance, composed of small cystic spaces lined by small cuboidal cells with clear cytoplasm, glycogen. The mean age of presentation is 66 years. Clear cell or glycogen rich adenomas are the widely used synonyms for this entity. It is proposed that the cell of origin is centroacinar cell or intercalated duct system. They can occur at any site in pancreas [1]. In some cases it is associated with von Hippel Lindau syndrome. Clinical symptoms include local discomfort or pain, obstruction if the tumor is in the pancreatic head and diabetes if sufficient numbers of islets are destroyed by the tumour. Excision is almost curative [2].

\section{Case Report}

A 70 year old male presented to the OPD with vague complaints of local discomfort and pain. Ultrasound showed a mass in the pancreas. CT scan showed areas of calcification. Pancreatectomy was done and we received the specimen. On gross examination, a well circumscribe mass was seen in the head of the pancreas measuring $3 \times 3 \mathrm{~cm}$ (Figure 1). Rest of the pancreas was normal. Multiple tiny cystic spaces were seen giving a spongy appearance. Histopathological examination

Manuscript received: $27^{\text {th }}$ April 2014

Reviewed: $15^{\text {th }}$ May 2014

Author Corrected: $20^{\text {th }}$ June 2014

Accepted for Publication: $5^{\text {th }}$ July 2014 revealed multiple cysts lined by cuboidal cells (Figure 2 ). The cells had clear cytoplasm and bland nucleus (Figure 3). A final diagnosis of Microcystic serous cystadenoma of pancreas was given. The surgery was uneventful and the patient was discharged.

\section{Discussion}

Serous cystic neoplasms of the pancreas are divided into two categories: microcystic and mucinous. Microcystic serous cystadenoma accounts for up to $10 \%$ of the total cystic neoplasms of pancreas. In a few number of cases, it is associated with Von Hippel Lindau disease. The chief complaints are abdominal mass with associated local pain and discomfort but in some cases they may be asymptomatic [3]. Grossly the tumor is large, multiloculated with sharply outlined cysts filled with clear fluid. It has a spongy consistency similar to infantile polycystic kidney. In some cases, a central stellate scar is present. The tumor may be macrocystic (megacystic, oligocystic, usually $<10$ cysts or microcystic (1$3 \mathrm{~mm})$. The predictors of aggressive behavior are large size of the tumor and location of the tumor in the head of pancreas [4]. Microscopic examination reveals small cystic spaces lined by cuboidal cells with clear cytoplasm (glycogen), and minimal mucin. Myoepithelial layer is intact and the cells have centrally placed hyperchromatic nuclei with occasionally

Available online at: www.ijmrr.in 382 | P a g e 


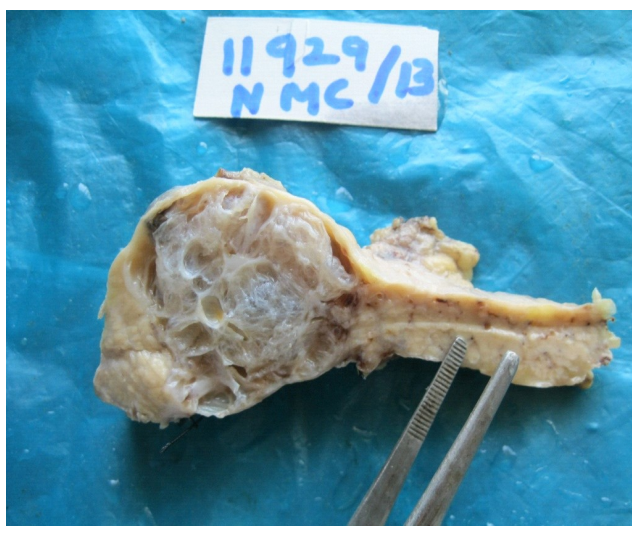

Fig 1: multiloculated with sharply outlined cysts

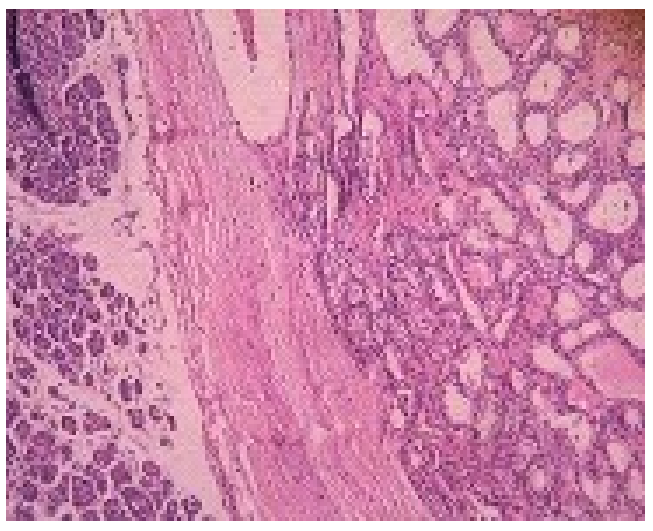

Fig 2: Microcystic serous cystadenoma, H\&E (10x)

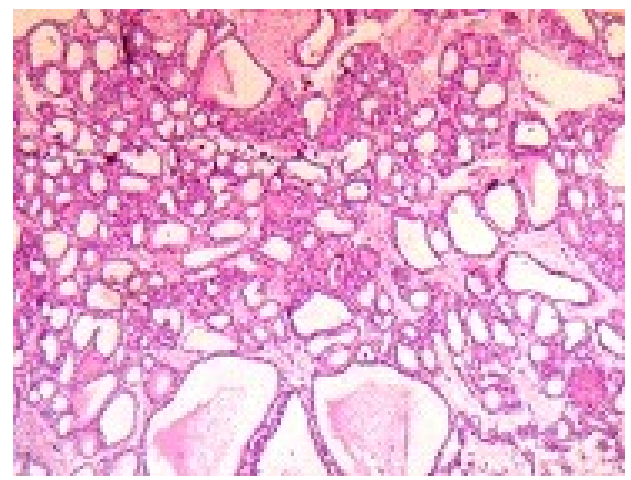

Fig 3: Microcystic serous cystadenoma, H\&E (40x)

papillae [5] and the islets between the lobules may calcify (radiating pattern). In a rare case, oncocytic change can be seen [6]. Another variant, the solid variant also exists where there are no cystic spaces and the cells are arranged in nests, sheets and trabeculae separated by thick fibrous bands [7]. Electron microscopic examination reveals prominent villi with glycogen granules and the epithelial cells are connected by occluding junctions and belt desmosomes resting on a basement membrane [8].

Imaging modalities are an aid in the diagnosis of serous cystadenoma of pancreas. On Ultrasound, more than six loculi, less than $2 \mathrm{~cm}$ in diameter are seen [9]. On plain CT, a sunburst pattern of calcification with a central scar is pathognomonic, but occurs in only $30 \%$ of patients [10]. On contrast-enhanced CT, enhancement occurs especially in the areas of septation [11].

The differential diagnosis of SCA is considered very important as SCAs may not require surgery. A misdiagnosis of pseudocysts or mucinous cystic tumors is always a possibility because of the oligocystic or unilocular nature in all these entities [12]. A majority of the patients with pseudocysts have a history of pancreatitis and often present at an elder age.
Hypervascularity is another feature distinguishing SCA from pseudocysts [13]. Endoscopic retrograde pancreatography has a distinct role in the differential diagnosis where a communication is seen with the pancreatic duct in case of the pseudocyst in $70 \%$ of the cases, whereas such a communication is absent in SCAs $[14,15]$. On CT scan, mucinous cystic tumors have a few, large loculi with thin septa and peripheral calcifications are seen in mucinous tumors and pseudocysts but in case of SCA, intratumoral calcifications are seen.

Fine-needle aspiration of cystic lesions for cytological and biochemical analysis of the fluid can be performed in cases where the distinction of SCAs from mucinous cystadenomas and pseudocysts is less clear by US or CT. On cytological analysis, periodic acid-Schiff stains show abundant cytoplasmic glycogen, and stains for mucins are negative in case of SCA [16].

The cells are cuboidal to polygonal in shape with no mitoses. Cytological analysis is diagnostic in about $50 \%$ to $60 \%$ of cases. Biochemical analysis of cyst fluid may include amylase and some tumor markers such as carcinoembryonic antigen, NB/70K, CA 72-4, CA 125, CA 15-3 tissue polypeptide antigen, and pS2 protein [17- 
19]. Amylase content of the fluid in SCAs is usually lower than the levels in pseudocysts and mucinous cystic tumors. SCAs have lower levels of tumor markers compared to mucinous cystic tumors.

We have presented this case because of its rarity, especially in men.

\section{Funding: Nil}

\section{Conflict of interest: Nil}

Permission from IRB: Yes

\section{References}

1. Laura,Webb, Lamps, Diagnostic Pathology Hepatobiliary and Pancreatic, In.Amirsys Publishing Inc;2011,11-5-14.

2. George DH, Murphy F, Michalski R, Ulmer BG. Serous cystadenoma of the pancreas: a new entity? Am J Surg Pathol 1989; 13(1):61-6.

3. Pancreas and periampullary region In, Rosai \& Ackermann Surgical Pathology, $9^{\text {th }}$ edition Mosby Publishers Vol I; 2010.

4. Lesandrowsky K. Macrocystic serous Cystadenoma of the Pancreas: A morphologic variant differing from Microcystic Adenoma.Hum Pathol 1992; 23:871

5. Bill A. Rampy, DO, PhD; Irving Waxman, MD; ShuYuan Xiao, MD; Roberto Logroño, MD.Serous Cystadenoma of the Pancreas With Papillary Features.A Diagnostic Pitfall on Fine-Needle Aspiration Biopsy. Arch Pathol Lab Med 2001; 125:1591

6. Panarelli NC, Park KJ, Hruban RH, Klimstra DS. Microcystic serous cystadenoma of the pancreas with subtotal cystic degeneration: another neoplastic mimic of pancreatic pseudocyst. Am J Surg Pathol 2012; 36:72631.
7. Perez-Ordonez $\mathrm{B}^{1}$, Naseem A, Lieberman $\mathrm{PH}$, Klimstra DS. Solid serous adenoma of the pancreas. The solid variant of serous cystadenoma? Am J Surg Pathol 1996; 20:1401-5

8. Pathology outlines.com

9. Johnson CD, Stephens DH, Charboneau JW, et al. Cystic pancreatic tumors: CT and sonographic assessment. AJR Am J Roentgenol 1988; 151: 1133-8.

10. Healy JC, Davies SE, Reznek RH. CT of microcystic (serous) pancreatic adenoma. J Comput Assist Tomogr 1994; 18:146-8.

11. Balthazar EJ, Chako AC. Computed tomography of pancreatic masses. Am J Gastroenterol 1990; 85: 343-9.

12. Warshaw AL, Rutledge PL. Cystic tumors mistaken for pancreatic pseudocysts. Ann Surg 1987; 205: 393-8.

13. Itai $\mathrm{Y}$, Ohhashi $\mathrm{K}$, Furui $\mathrm{S}$, et al. Microcystic adenoma of the pancreas: spectrum of computed tomographic findings. J Comput Assist Tomogr 1988; 12: 797-803.

14. O'Connor M, Kolars J, Ansel U, et al. Preoperative endoscopic retrograde cholangiopancreatography in the surgical management of pancreatic pseudocysts. Am J Surg 1986; 151: 18-24.

15. Yamaguchi K, Chijiwa K, Shimizu S, et al. Comparison of endoscopic retrograde and magnetic resonance cholangiopancreatography in the surgical diagnosis of pancreatic diseases. Am J Surg 1998; 175: 203-8.

16. Laucirica R, Schwartz MR, Ramzy I. Fine needle aspiration of pancreatic cystic epithelial neoplasms. Acta Cytologica 1992; 36: 881-6.

\section{How to cite this article?}

Grandhi B, Shanthi V, Rao NM, Reddy VC, Mohan KM. Pancreatic serous cystadenoma - A case report. Int J Med Res Rev 2014;2(4):382-384. doi:10.17511/ijmrr.2014.i04.20 